\title{
PENERAPAN KURVA BEZIER KARAKTER SIMETRIK DAN PUTAR PADA MODEL KAP LAMPU DUDUK MENGGUNAKAN MAPLE
}

\author{
1Juhari, ${ }^{2}$ Erny Octafiatiningsih \\ ${ }^{1,2}$ Jurusan Matematika, Universitas Islam Negeri Maulana Malik Ibrahim Malang
}

Email: jo alkanderi57@yahoo.co.id, erny.octafia1710@gmail.com

\begin{abstract}
ABSTRAK
Penelitian ini bertujuan untuk memperoleh prosedur mengkonstruksi bentuk kap lampu duduk melalui penggabungan dan pemilihan parameter pengubah bentuk permukaan Bezier. Sehingga, menghasilkan kap lampu duduk secara utuh yang simetri dan bervariasi. Pada pembuatan kap lampu duduk memerlukan studi tentang aspek fisis (pencahayaan) maupun geometri. Dari segi geometri, model pembuatan kap lampu duduk yang telah ada pada umumnya monoton dan terbangun dari suatu model potongan benda. Sehubungan dengan permasalahan tersebut maka penelitian ini dibagi menjadi empat tahap yaitu: Pertama, menyiapkan data untuk membangun kap lampu duduk. Kedua, studi teknik untuk membangun kesimetrian bentuk kap lampu duduk. Ketiga, mengkonstruksi bagianbagian kap lampu duduk (bagian alas, bagian utama, bagian atap), dan Keempat, mengkonstruksi kap lampu duduk secara utuh. Hasil penelitian ini mendapatkan prosedur mengkonstruksi kap lampu duduk yaitu: Pertama, membagi sumbu utama menjadi tiga sumbu sub segmen non homogen. Kedua, Membangun bagian-bagian dari kap lampu duduk (bagian alas, bagian utama, bagian atap) dengan cara menggabungkan komponen-komponen kap lampu duduk hasil deformasi benda-benda geometri. Ketiga, mengisi setiap bagian sub segmen non homogen dengan bagian-bagian dari kap lampu dan membangun kurva batas sehingga menghasilkan model kap lampu duduk yang bervaiasi, inovasi dan simetri.
\end{abstract}

Kata kunci: Kap Lampu Duduk, Kura Hermit, Kurva Bezier

\begin{abstract}
This research aimed to obtain construction procedures lampshade form through incorporation and election of parameters shape shifter Bezier surface. Thus, it product a sholid lampshade that both symmetrical and varied. In contruction lampshade it requires learning about the physical (expose) and geometrical aspects. In terms of geometry model-making of lampshade sitting which has existed in general still monotone and built of object cut model. Dealing with the problem, so this research is divided into four stages: Firstly, prepare the data of building sitting lampshade. Secondly, study about technique of building symmetrical sitting lampshade. Thirdly, construct overall lampshade. The results of this research is procedures by contruction of sitting lampshade: First, The main axis split into three sub segments axis non-homogeneous. Second, build parts of the sitting lampshade (the base, the main part, the roof) by combining the components lampshade deformation results geometry objects. Third, fill each sub-segment of non-homogeneous parts with parts of the lampshade and build a boundary curve resulting lampshade varied models, innovation, and symmetry.
\end{abstract}

Keywords: Bezier Curve, Hermit Curve, Standing Lamp Shading

\section{PENDAHULUAN}

Geometri merupakan cabang matematika yang mempelajari tentang garis, sudut, bidang, benda-benda ruang dan sifat-sifat serta hubungnnya dengan yang lain. Geometri mempunyai banyak kegunaan dalam kehidupan sehari-hari. Benda-benda yang ada di alam raya ini mempunyai bentuk geometri berbentuk bidang maupun ruang. Walaupun benda-benda yang dijumpai tidak sempurna, namun dapat digambarkan atau ditunjukkan kemiripannya terhadap bangun geometri tertentu. Pada perkembangannya geometri dapat digolongkan berdasarkan ruang atau bidang kajian, yaitu geometri bidang (dua-dimensi), geometri ruang (tiga-dimensi), dan geometri dimensi $n$. Geometri bidang dan ruang dapat digunakan sebagai sarana untuk mendesain model kerajinan, seperti kap lampu, vas bunga, knop, guci, dan lain-lain.

Kap lampu duduk merupakan salah satu aksesoris didalam desain interior ruangan. Selain berfungsi sebagai penerangan, lampu kini mengalami perkembangan dengan banyak inovasi. Pada dasarnya kap lampu duduk dapat ditempatkan di setiap sudut ruangan. Akan tetapi, 
tidak dapat sebarang memilih kap lampu duduk yang akan dipakai didalam ruangan. Ragam model dan ukuran kap lampu duduk yang bervariasi dapat disesuaikan dengan kebutuhan ruangan. Bentuk dan model yang selalu up to date dan cahayanya dapat membuat ruangan terlihat lebih indah.

Pembuatan kap lampu duduk memerlukan studi tentang aspek fisis (pencahayaan) maupun geometris. Dari segi geometris, model pembuatan kap lampu duduk yang telah ada pada umumnya masih monoton dan terbangun dari satu model potongan benda. Hal ini dapat dilihat dari produk industri kap lampu duduk yang masih sederhana dan teknik desain yang digunakan masih menggunakan cara konvensional. Teknik tersebut membutuhkan waktu yang sangat lama sehingga pesanan pelanggan sering tidak selesai pada waktunya. Selain itu produk yang dihasilkan pengrajin yang menggunakan teknik desain konvensional pada umumnya model yang dihasilkan tidak berubah (tetap), tidak diimbangi oleh peningkatan seni dan inovasi yang dibutuhkan oleh pelanggan yang sangat beragam ditinjau dari aspek tingkat kesimetrian, keserasian, dan variasi model maupun dari aspek ragam jenis dan ukuran barang yang ditawarkan.

Artikel ini merupakan upaya ilmiah untuk memperoleh model-model kap lampu duduk yang inovatif dan bervariasi. Artikel ini dilakukan upaya mengknstruksi kap lampu duuk, sehingga dapat diketahui prosedur mengkonstruksi kap lampu duduk.

\section{KAJIAN TEORI}

\section{Kurva Hermit Kuadratik}

Bentuk kurva Hermit adalah

$P(u)=P(0) K_{1}(u)+P(1) K_{2}(u)+P^{\prime}(1) K_{3}(u)$

dengan:

$K_{1}(u)=\left(1-2 u+u^{2}\right)$

$K_{2}(u)=\left(2 u-u^{2}\right)$

$K_{3}(u)=\left(-u+u^{2}\right)$

$P(0)=$ titik awal kurva berbentuk $\left(x_{0}, y_{0}, z_{0}\right)$

$P(1)=$ titik akhir kurva berbentuk $\left(x_{1}, y_{1}, z_{1}\right)$

$P^{\prime}(1)=$ titik kontrol kelengkungan kurva dengan

$$
0 \leq u \leq 1
$$

\section{Kurva Bezier Berderajat Dua}

Kurva Bezier berderajat-dua dinyatakan dalam bentuk parametrik yaitu:

$V(u)=K_{0}\left(1-2 u+u^{2}\right)+K_{1}\left(2 u-2 u^{2}\right)+$ $K_{2}\left(u^{2}\right)$
[2]

Contoh:

Diketahui $K_{0}=(5,0,0) ; K_{1}=(10,0,3)$ dan $K_{2}=(7,0,5)$, maka kurva Bezier berderajat dua dapat dinyatakan sebagai berikut:

$$
\begin{aligned}
& V(u)=(5,0,0)\left(1-2 u+u^{2}\right)+(10,0,5)(2 u- \\
&\left.2 u^{2}\right)+(7,0,5)\left(u^{2}\right) \\
&=\left(5\left(1-2 u+u^{2}\right), 0\left(1-2 u+u^{2}\right), 0(1-\right. \\
&\left.\left.2 u+u^{2}\right)\right)+\left(10\left(2 u-2 u^{2}\right), 0(2 u-\right. \\
&\left.\left.2 u^{2}\right), 5\left(2 u-2 u^{2}\right)\right)+\left(7\left(u^{2}\right), 0 u^{2}, 5\left(u^{2}\right)\right) \\
&=\left(5-10 u+5 u^{2}, 0,0\right)+(20 u- \\
&\left.20 u^{2}, 0,10 u-10 u^{2}\right)+\left(7 u^{2}, 0,5 u^{2}\right) \\
&=\left(5+10 u-8 u^{2}, 0,6 u-u^{2}\right) \\
& \text { dengan } 0 \leq u \leq 1 \text { sehingga diperoleh kurva }
\end{aligned}
$$
seperti pada (Gambar 1).

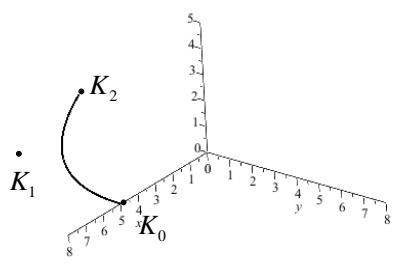

Gambar 1. Kurva Bezier Berderajat Dua

\section{Perputaran (Rotasi)}

Rotasi adalah perubahan dari suatu koordinat objek ke dalam kedudukan baru dengan menggerakkan seluruh titik koordinat yang didefinisikan pada bentuk awal dengan suatu besaran sudut pada suatu sumbu putar. Jika $Q\left(x_{q}, y_{q}, z_{q}\right)$ adalah posisi setelah rotasi pada sumbu putar, $P\left(x_{p}, y_{p}, z_{p}\right)$ adalah posisi awal sebelum dilakukan rotasi, dan $R$ adalah matriks rotasi pada suatu sumbu putar. Sistem koordinat $R^{3}$ mempunyai tiga sumbu putar, maka rotasi setiap sumbu dapat ditulis sebagai berikut, dengan $\theta$ menunjukkan sudut putar.

a. Rotasi terhadap sumbu $X$

$\left(x_{q}, y_{q}, z_{q}\right)=\left(x_{p}, y_{p} \cdot \cos \theta-z_{p} \cdot \sin \theta, y_{p}\right.$.

$$
\left.\sin \theta+z_{p} \cdot \cos \theta\right)
$$

b. Rotasi terhadap sumbu $Y$

$\left(x_{q}, y_{q}, z_{q}\right)=\left(x_{p} \cdot \cos \theta+z_{p} \cdot \sin \theta, y_{p}\right.$

$$
\left.x_{p} \cdot(-\sin \theta)+z_{p} \cdot \cos \theta\right)
$$

c. Rotasi terhadap sumbu $Z$

$\left(x_{q}, y_{q}, z_{q}\right)=\left(x_{p} \cdot \cos \theta+y_{p} \cdot \sin \theta\right.$,

$$
\left.x_{p} \cdot(-\sin \theta)+y_{p} \cdot \cos \theta, z_{p}\right)
$$

dengan $0 \leq u \leq 1$ 


\section{Pergeseran}

Jika $P\left(x_{p}, y_{p}, z_{p}\right)$ adalah posisi titik asal, $Q\left(x_{q}, y_{q}, z_{q}\right)$ adalah posisi setelah titik digeser, $I$ adalah matriks identitas, dan $\left(t r_{x}, t r_{y}, t r_{z}\right)$ merupakan nilai konstanta yang menunjukkan besarnya penggeseran pada setiap sumbu koordinat, maka hasil penggeseran dapat dinyatakan sebagai berikut [3].

$$
\left(x_{q}, y_{q}, z_{q}\right)=\left(x_{p}+t r_{x}, y_{p}+t r_{y}, x_{p}+t r_{x}\right)
$$

\section{Interpolasi di Antara Segmen Garis dan Kurva di Ruang}

Misalkan terdapat dua segmen garis $\overline{A B}$ dan $\overline{C D}$ didefinisikan masing-masing oleh $A\left(x_{1}, y_{1}, z_{1}\right)$, $B\left(x_{2}, y_{2}, z_{3}\right), C\left(x_{3}, y_{3}, z_{3}\right)$ dan $D\left(x_{4}, y_{4}, z_{4}\right)$ dalam bentuk parametrik $I_{1}(u)$ dan $I_{2}(u)$, maka permukaan parametrik hasil interpolasi linier kedua segmen garis tersebut diformulasikan,

$$
S(u, v)=(1-v) I_{1}(u)+v I_{2}(u)
$$

dengan $0 \leq u \leq 1$ dan $0 \leq v \leq 1$

Terdapat beberapa kasus khusus bentuk interpolasi linier kedua garis tersebut. Jika $A=B$ maka hasil interpolasi persamaan (7) akan menghasilkan bidang segitiga. Jika $\overline{A B} / / \overline{C D}$ maka secara umum akan membentuk bidang segiempat. Jika bidang tersebut dibentuk dari interpolasi dua garis yang bersilang maka menghasilkan permukaan yang tidak datar (dapat berbentuk lengkung maupun puntiran) di sebagian permukaan tersebut [4]

Dapat dibangun permukaan lengkung hasil interpolasi kurva ruang melalui persamaan berikut:

$$
S(u, v)=(1-v) C_{1}(u)+v C_{2}(u)
$$

dengan $C_{1}(u)$ dan $C_{2}(u)$ merupakan kurva batas (Gambar 3) [4]

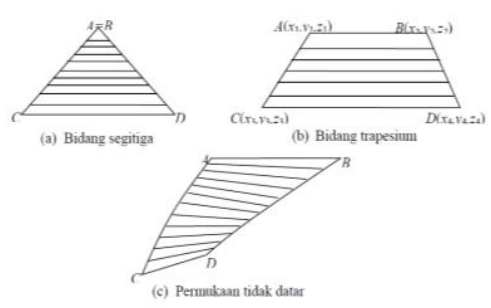

Gambar 2. Contoh Kasus Khusus Interpolasi Linier Dua Segmen Garis

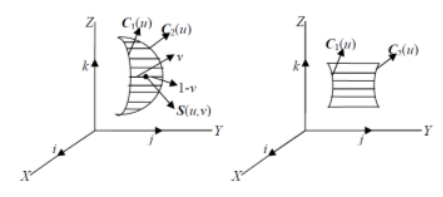

Gambar 3. Interpolasi Linier pada Kurva

\section{Dilatasi Titik Pada $\boldsymbol{R}^{3}$}

Transformasi dilatasi yang memetakkan titik $P(x, y, z)$ ke $P^{\prime}\left(x^{\prime}, y^{\prime}, z^{\prime}\right)$ didefinisikan dengan bentuk formula berikut:

$$
\left[\begin{array}{l}
x^{\prime} \\
y^{\prime} \\
z^{\prime}
\end{array}\right]=\left[\begin{array}{ccc}
k_{1} & 0 & 0 \\
0 & k_{2} & 0 \\
0 & 0 & k_{3}
\end{array}\right]\left[\begin{array}{l}
x \\
y \\
z
\end{array}\right]
$$

Dalam hal ini pemilihan nilai $k_{1}$ menyajikan sekala ke arah sumbu $X, k_{2}$ ke arah sumbu $Y$ dan $k_{3}$ menyajikan skala ke arah sumbu $Z$, jika $k_{1}=$ $k_{2}=k_{3}$, maka peta objek yang didapat sebangun dengan objek aslinya (diperbesar, diperkecil; atau tetap) [1].

Misalkan segitiga $P Q R$ dengan titik-titik sudut $P\left(x_{1}, y_{1}, z_{1}\right), Q\left(x_{2}, y_{2}, z_{2}\right)$ dan $R\left(x_{3}, y_{3}, z_{3}\right)$ didilatasikan dengan faktor pengali $k>1$, sehingga didapatkan segitiga bayangan $P^{\prime} Q^{\prime} R^{\prime}$ dengan titik-titik sudut $P^{\prime}\left(k x_{1}, k y_{1}, k z_{1}\right)$, $Q^{\prime}\left(k x_{2}, k y_{2}, k z_{2}\right)$ dan $R^{\prime}\left(k x_{3},{ }^{9} y_{3}, k z_{3}\right)$ seperti terlihat pada (Gambar 4)

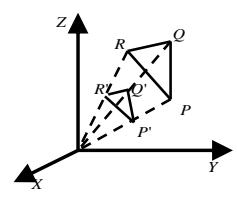

Gambar 4. Kurva Bezier Berderajat Dua

\section{Penyajian Benda-benda Geometri Ruang}

a. Penyajian Tabung

Jika diketahui tabung dengan pusat alas $P_{1}\left(x_{1}, y_{1}, z_{1}\right)$ dengan jari-jari $r$ dan tinggi $t$ dapat di gambar dengan menggunakan persamaan sebagai berikut:

Jika sumbu pusat tabung sejajar sumbu $Z$

$$
T(\theta, z)=\left(x_{1}+r \cos \theta, y_{1}+r \sin \theta, z\right)
$$

dengan $0 \leq \theta \leq 2 \pi$ dan $r \in \mathbb{R}$

Jika sumbu pusat tabung sejajar smbu $X$

$$
T(\theta, z)=\left(x, y_{1}+r \sin \theta, z_{1}+r \cos \theta\right)
$$

dengan $0 \leq \theta \leq 2 \pi$ dan $x_{1}<x \leq x_{1}+t$ Jika sumbu pusta tabung sejajar sumbu $Y$

$$
T(\theta, z)=\left(x_{1}+r \cos \theta, y, z_{1}+r \sin \theta\right)
$$

dengan $0 \leq \theta \leq 2 \pi$ dan $y_{1} \leq y \leq y_{1}+t[5]$.

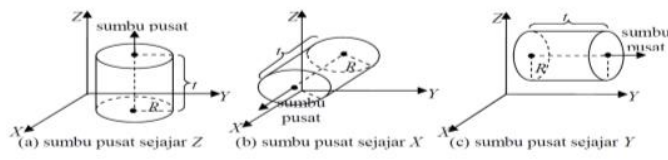

Gambar 5. Tabung dengan Beragam Sumbu Pusat 
Menyatakan persamaan parametrik bola dengan pusat $Q(a, b, c)$ dan jari-jari $r$, yaitu: $B(\theta, \beta)=(r \sin \theta \cos \beta+a, r \cos \theta+c$, $r \sin \theta \sin \beta+b)$

dengan paramer $0 \leq \theta \leq 2 \pi$ dan $0 \leq \beta \leq$ $2 \pi[5]$.

\section{Konstruksi Objek Pada Program Maple}

Disajikan contoh bahasa pemrograman menggunakan softwere Maple 15 untuk mengkonstruksi objek geometri.

a. Mengkonstruksi Segmen Garis

Untuk membangun segmen garis $\overline{A B}$ dengan titik $A(3,2,4)$ dan titik $B(9,8,12)$ pada Maple 15 (Gambar 2.23), dengan menggunakan persamaan sebagai berikut:

$P(u)=a+b u$

$P(0)=a$

$P(1)=a+b$

sehingga $P(u)=P(0)+P(1) u$

dimana $P(0)=$ titik awal kurva

$P(1)=$ titik akhir kurva

$$
\begin{aligned}
(x, y, z)= & \left(x_{A}+u \cdot\left(x_{B}-x_{A}\right), y_{A}+u \cdot\right. \\
& \left.\left(y_{B}-y_{A}\right), z_{A}+u \cdot\left(z_{B}-z_{A}\right)\right)
\end{aligned}
$$

yaitu,

maka dapat ditulis dengan script program $>$ plot $3 \mathrm{~d}\left(\left[3+\mathrm{u}^{*}(9-3), 2+\mathrm{u}^{*}(8-2), 4+\mathrm{u}^{*}(12-\right.\right.$

$4)], u=0 . .1)$;

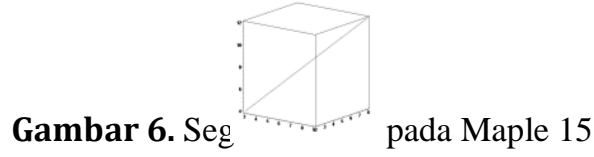

\section{b. Megkonstruksi Tabung}

Tabung adalah sebuah bidang yang dibentuk oleh lingkaran yang berjari-jari $r$ dan bergerak secara paralel pada sumbu pusat sepanjang $t$. Contoh penulisan script pada Maple 15 untuk mengkonstruksi tabung dengan menggunakan persamaan (11) seperti pada (Gambar 7) adalah: $* \mathrm{Pi}, \mathrm{v}=0 . .4)$;

$>\operatorname{plot} 3 \mathrm{~d}\left(\left[4^{*} \cos (\mathrm{u})+4,4^{*} \sin (\mathrm{u})+4,4^{*} \mathrm{v}\right], \mathrm{u}=0 . .2\right.$

Tabung terbentuk dari bidang lingkaran berpusat di $x=4$ dan $y=4$ dan $r=4$ dengan ketinggian $z=4 v$ dengan $v$ interval dari 0 sampai 4.

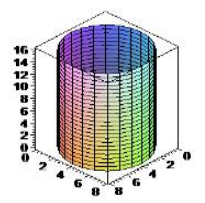

Gambar 7. Tabung pada Maple 15

c. Mengkonstruksi Bola

Untuk mengkonstruksi bola dengan jari-jari

3 dan berpuata di titik $(1,4,3)$ dengan menggunakan persamaan (13) seperti pada (Gambar 8) pada Maple 15 adalah:

$$
>\operatorname{plot} 3 \mathrm{~d}\left(\left[3^{*} \sin (\mathrm{v}) * \cos (\mathrm{u})+1\right.\right. \text {, }
$$

$\left.3^{*} \sin (\mathrm{v}) * \sin (\mathrm{u})+4,3^{*} \cos (\mathrm{v})+3\right], \mathrm{u}=0$.. $2^{*} \mathrm{Pi}, \mathrm{v}=0$.. 2*Pi);

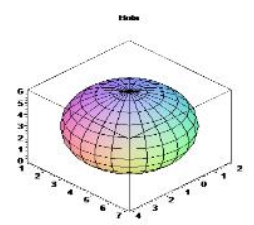

Gambar 8. Bola pada Maple 15

\section{PEMBAHASAN}

Di dalam artikel ini dijelaskan bagaimana prosedur untuk mengkonstruksi kap lampu duduk. Prosedur yang pertama yaitu mengkonstruksi komponen-komponen kap lampu duduk duduk yang akan digunakan. Langkah selanjutnya yaitu mengkonstruksi bagian-bagian kap lampu duduk yaitu bagian alas, bagian utama dan bagian atap. Prosedur yang terakhir yaitu mengkonstruksi kap duduk secarah utuh.

A. Mengkonstruksi Kompnen-komponen Kap Lampu Duduk

1. Mendeformasi Tabung

Misalkan diberikan tabung yang berjari-jari $r$, batas minimum jari-jari tabung yaitu $10 \mathrm{~cm}$ sedangkan batas maximum jari-jari tabung yaitu $20 \mathrm{~cm}$, tinggi minimum tabung yaitu $10 \mathrm{~cm}$ sedangkan tinggi maximum tabung yaitu $30 \mathrm{~cm}$, dan alas berpusat di $P\left(x_{0}, y_{0}, z_{0}\right)$. Sehingga, selang ukuran tabung yaitu $10 \mathrm{~cm} \leq t \leq 30 \mathrm{~cm}$ dan $10 \mathrm{~cm} \leq r \leq 20 \mathrm{~cm}$. Pemilihan nilai $r$ dan $t$ dalam selang tersebut bertujuan untuk perbedaan ukuran bentuk komponen penyusun kap lampu duduk. Berdasarkan data tersebut didesain beragam bentuk komponen penyusun kap lampu duduk menggunakan teknik modifikasi kurva selimut dan teknik dilatasi lengkung selimut.

Algoritma untuk mendoformasi tabung dengan modifikasi pada kurva selimut adalah sebagai berikut:

a. Ditentukan titik pusat pada lingkaran alas tabung yaitu $\left(x_{1}, y_{1}, z_{1}\right)=(0,0,0)$, bangun lingkaran alas tabung dengan menggunakan persamaan lingkaran dan menetapkan nilai $\theta=0$ sehingga didapat satu titik yaitu $P(0)$.

$$
\begin{aligned}
P(0) & =\left(x_{1}+r_{1} \cos \theta, y_{1}+r_{1} \sin \theta, z_{1}\right) \\
& =\left(r_{1}, 0,0\right)
\end{aligned}
$$

b. Ditentukan titik pusat pada lingkaran atap tabung yaitu $\left(x_{1}, y_{1}, z_{1}\right)=(0,0, t)$, bangun lingkaran atap tabung dengan dengan menggunakan persamaan lingkaran dan menetapkan nilai $\theta=0$ sehingga didapatkan satu titik yaitu $P(1)$.

$$
\begin{aligned}
P(1) & =\left(x_{1}+r_{2} \cos \theta, y_{1}+r_{2} \sin \theta, z_{1}\right) \\
& =\left(r_{2}, 0, t\right)
\end{aligned}
$$


c. Ditentukan titik kontrol $P^{\prime}(1)$ untuk mengontrol kelengkungan kurva Hermit sehingga

$$
P^{\prime}(1)=(x, 0, z)
$$

$$
\text { dengan }-2 r \leq x, z \leq 2 t \text { dan } x, z \in \mathbb{R} \text {. }
$$

d. Kurva Hermit dibangun dengan mensubtitusikan nilai $P(0), P(1)$ dan $P^{\prime}(1)$ ke persamaan (1) sehingga didapat

$$
\begin{gathered}
P(u)=\left(r H_{1}(u)+r H_{2}(u)+x H_{3}(u), 0 H_{1}(u)+\right. \\
0 H_{2}(u)+0 H_{3}(u), 0 H_{1}(u)+t H_{2}(u)+ \\
\left.z H_{3}(u)\right) \\
\text { dengan } \\
H_{1}(u)=\left(1-u-u^{2}\right) \\
H_{2}(u)=\left(2 u-u^{2}\right) \\
H_{3}(u)=\left(-u+u^{2}\right) \\
0 \leq u \leq 1
\end{gathered}
$$

e. Kurva Hermit diputar terhadap sumbu $Z$ dengan menggunakan persamaan (5) dan $0 \leq$ $\theta \leq 360^{\circ}$ sehingga

$$
\begin{array}{r}
P(u)=\left(\left(r H_{1}(u)+r H_{2}(u)+x H_{3}(u)\right) \cos \theta,\right. \\
\left(r H_{1}(u)+r H_{2}(u)+x H_{3}(u)\right) \sin \theta, \\
\left.0 H_{1}(u)+t H_{2}(u)+t H_{3}(u)\right)
\end{array}
$$

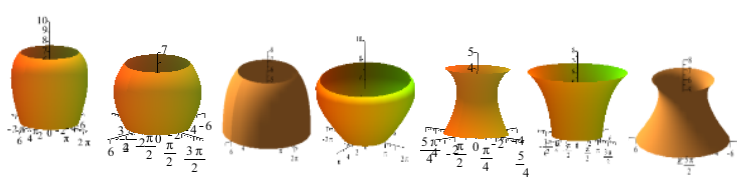

Gambar 9. Variasi Hasil Deformasi Tabung

2. Mendeformas Prisma Segi Enam

Misalkan diberikan prisma segienam beraturan dengan koordinat pasangan titik ujung rusuk $\left[K_{i}\left(x_{i}, y_{i}, z_{i}\right), K_{i}^{\prime}\left(x_{i}, y_{i}, z_{i}+t\right)\right]$ dengan $i=$ $1,2,3, \ldots, 6$ dan tinggi $t$ dengan $5 \mathrm{~cm} \leq t \leq 15 \mathrm{~cm}$. masing-masing tutupnya bertitik berat dititik $K\left(x_{0}, y_{0}, z_{0}\right)$ dan $K^{\prime}\left(x_{0}, y_{0}, z_{0}+t\right)$. Jarak titik $\mathrm{K}$ ke $K_{I}$ dan $K^{\prime}$ ke $K_{i}^{\prime}$ adalah $6 \mathrm{~cm} \leq r \leq 10 \mathrm{~cm}$. Dalam hal ini, $\overline{K K^{\prime}}$ diambil sebagai sumbu simetri deformasi prisma segienam.

Langkah-langkah deformasi sisi tegak prisma menjadi lengkung cekung yaitu:

a. Ditentukan $K_{i}$ dan $K_{i}^{\prime}$ dengan $i=0,1,2,3,4,5$ sebagai titik kontrol untuk beberapa kurva Bezier linier dengan menggunakan persamaan lingkaran dengan menetapkan $\theta=\frac{i \pi}{3} \operatorname{dan}\left(x_{1}, y_{1}, z_{1}\right)=(0,0,0)$.

$$
\begin{aligned}
K_{i}(\theta) & =\left(r \cos \frac{i \pi}{3}, r \sin \frac{i \pi}{3}, 0\right) \\
K_{i}{ }^{\prime}(\theta) & =\left(r \cos \frac{i \pi}{3}, r \sin \frac{i \pi}{3}, t\right)
\end{aligned}
$$

b. Ditetapkan titik kontrol $Q$ untuk mengontrol kelengkungan kurva Bezier kuadratik

$$
Q=\left(x_{0}, y_{0}, z\right) \quad \text { dengan } z \in\left[z_{0}, t\right] .
$$

c. Kurva Bezier berderajat dua untuk setiap pasang titik kontrol $\left(K_{i}, Q, K_{i}^{\prime}\right)$ dibangun dengan menggunakan persamaan (2)

$$
\begin{gathered}
V_{i}(u)=(1-u)^{2} K_{i}+2(1-u)(u) Q+u^{2} K_{i}^{\prime} \\
\text { dengan } 0 \leq u \leq 1 .
\end{gathered}
$$

d. Diinterpolasikan secara linier masing-masing kurva Bezier melalui persamaan (8) secara berpasangan dan berurutan berlawanan arah jarum jam

$$
\begin{aligned}
\mathrm{S}(\mathrm{u}, \mathrm{v})= & \left((1-v)(1-u)^{2} r \cos \frac{i \pi}{3}+\right. \\
& (1-v)\left(2 u-2 u^{2}\right) x_{0}+ \\
& (1-v) u^{2} r \cos \frac{i \pi}{3}+v(1- \\
& u)^{2} r \cos \frac{(i+1) \pi}{3}+v\left(2 u-2 u^{2}\right) x_{0}+ \\
& v u^{2} r \cos \frac{(i+1) \pi}{3},(1-v)(1- \\
& u)^{2} r \sin \frac{i \pi}{3}+(1-v)(2 u- \\
& \left.2 u^{2}\right) y_{0}+(1-v) u^{2} r \sin \frac{i \pi}{3}+ \\
& v(1-u)^{2} r \sin \frac{(i+1) \pi}{3}+ \\
& v\left(2 u-2 u^{2}\right) y_{0}+v u^{2} r \sin \frac{(i+1) \pi}{3}, \\
& (1-v)(1-u)^{2} 0+(1-v)(2 u- \\
& \left.2 u^{2}\right) z+(1-v) u^{2} 0+v 0(1- \\
& \left.u)^{2}+v\left(2 u-2 u^{2}\right) z+v 0 u^{2}\right)
\end{aligned}
$$

dengan $0 \leq v \leq 1$ dan $0 \leq u \leq 1$

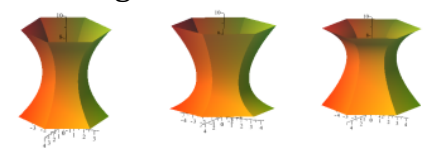

Gambar 10. Variasi Hasil Deformasi Tabung

B. Mengkonstruksi Bagian-bagian Kap Lampu Dudu

Sebelum dilakukan perangkaian bagianbagian kap lampu duduk yang dilakukan terlebih dahulu yaitu menetapkan sumbu sepanjang tinggi kap lampu duduk kemudian membagi segmen tersebut menjadi tiga sub segmen non-homogen yaitu $\overline{S_{3} S_{4}}$ bagian alas, $\overline{S_{2} S_{3}}$ bagian utama, dan $\overline{S_{1} S_{2}}$ bagian atap.

1. Merangkai Alas Kap Lampu Duduk

Langkah-langkah penyusunan alas kap lampu duduk:

a. Bagian $\overline{S_{3} S_{4}}$ diisi dengan komponenkomponen kap lampu duduk.

b. Dipilih parameter-parameter pengubah bentuk permukaan seperti ukuran dan titik kontrol kelengkungan sehingga didapat bentuk kap lampu duduk bagian alas yang diinginkan.

c. Dibangun bidang tutup bawah dengan prosedur sebagai berikut.

1) Ditetapkan lingkaran tutup bawah bagian alas dengan jari-jari $r_{1}$; 
2) Dibangun bola dengan jari-jari $r_{1}$ dengan $z=0$ sebagai tutup bawah dengan persamaan (13).
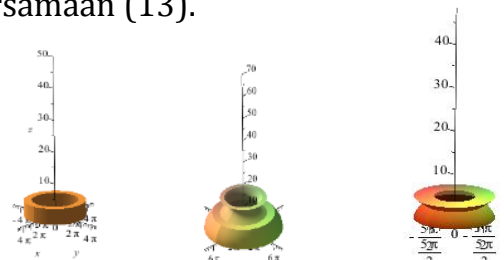

Gambar 11. Beberapa Variasi Alas Kap Lampu Duduk

2. Mengkonstruksi Bagian Utama Kap Lampu Duduk

Langkah-langkah penyusunan bagian utama kap lampu duduk yang terbentuk dari beberapa benda dasar sebagi berikut:

a. Segmen garis $\overline{S_{2} S_{3}}$ dibagi menjadi beberapa sub segmen.

b. Setiap sub segmen diisi dengan komponenkomponen kap lampu duduk.

1) Sub segmen bagian bawah diisi dengan komponen kap lampu duduk.

2) Dipilih parameter pengubah bentuk permukaan komponen kap lampu duduk seperti ukuran dan titik kontrol kelengkungan sehingga didapat komponen kap lampu duduk sesuai keinginan.

3) Dilakukan langkah 1) dan 2) untuk mengisi sub segmen selanjutnya kemudian translasikan komponen tersebut searah sumbu $Z$ sejauh panjang sub segmen sebelumnya.

4) Dilakukan langkah 1) sampai 3) untuk mengisi sub segmen selanjutnya hingga bagian sub segmen dari segmen garis $\overline{S_{2} S_{3}}$ terisi semua.

c. Beberapa bangun komponen bagian utama kap lampu duduk digabung dengan cara membangun bidang batas antara dua komponen berdekatan dengan prosedur sebagai berikut.

1) Ditetapkan lingkaran tutup atas bagian komponen kap lampu duduk yang pertama dengan jari-jari $r_{1}$ sebagai kurva batas $C_{1}(u)$.

2) Ditetapkan lingkaran tutup bawa bagian komponen kap lampu duduk yang kedua dengan jari-jari $r_{2}$ sebagai kurva batas $C_{2}(u)$.

3) Dibangun bidang batas antara $C_{1}(u)$ dan $C_{2}(u)$ dengan interpolasi linier menggunaan persamaan (8).

4) Dilakukan langkah (a) sampai (c) untuk membangun bidang batas antara bagian komponen-komponen utama kap lampu duduk.

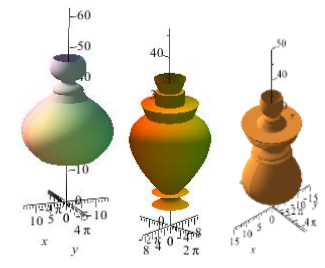

Gambar 12. Variasi Bagian Utama

3. Mengkonstruksi Bagian Atap Kap Lampu Duduk

Langkah-langkah penyusunan atap kap lampu duduk:

a. Bagian $\overline{S_{1} S_{2}}$ diiisi dengan komponenkomponen kap lampu duduk.

b. Dibangun bidang tutup atas dengan prosedur sebagai berikut.

Jika permukaan atas berbentuk lingkaran.

1) Ditetapkan lingkaran tutup atas bagian alas dengan jari-jari $r_{1}$.

2) Dibangun bola dengan jari-jari $r_{1}$ dengan $z=0$ tutup bawah dengan persamaan (13).

Jika permukaan atas berbentuk segienam.

1) Ditetapkan titik kontrol $K_{i}$ dengan $i=$ $0,1,2,3,4$, dan 5 pada poligon segienam bagian atas atap kap lampu duduk dengan menggunakan persamaan (10), menetaapkan $\theta=\frac{i \pi}{3}$ dan $r$ merupakan jarak antara titik $S_{1}$ dengan $K_{i}$ sehingga

$$
K_{i}=\left(r \cos \frac{i \pi}{3}, r \sin \frac{i \pi}{3}, t\right)
$$

2) Diinterpolasikan secara linier masingmasing pasangan titik kontrol dengan menggunakan persamaan (8) sehingga

$S(u, v)=\left((1-v) r \cos \frac{i \pi}{3}+(1-\right.$

v) $u r \cos \frac{(i+1) \pi}{3}+(1-$

v) $u r \cos \frac{i \pi}{3}+0 v,(1-$

v) $r \sin \frac{i \pi}{3}+(1-$

v) $u r \sin \frac{(i+1) \pi}{3}+(1-$

v) $u r \sin \frac{i \pi}{3}+0 v,(1-v) t+$

$(1-v) u t+(1-v) u t+t v)$ 


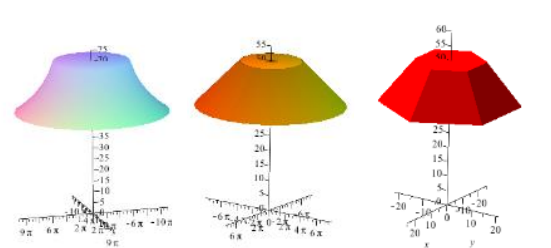

Gambar 13. Variasi Bagian Utama

\section{Mengkonstruksi Kap Lampu Secarah Utuh}

Selanjutnya untuk mendapatkan bentuk utuh kap lampu duduk yang tergabung secara kontinyu pada bagian ini dilakukan perangkaian beberapa benda-benda dasar komponen kap lampu duduk dengan cara menggabungkan komponen-komponen bagian dari kap lampu duduk.

Langkah-langkah perangkaian kap lampu duduk secara utuh:

1. Bagian segmen garis $\overline{S_{3} S_{4}}$ diisi dengan komponen bagian alas kap lampu duduk.

2. Bagian segmen garis $\overline{S_{2} S_{3}}$ diisi dengan komponen bagian utama kap lampu duduk dan sesuaikan tingginya.

3. Bagian segmen garis $\overline{S_{2} S_{1}}$ diisi dengan komponen bagian atap kap lampu duduk dan sesuaikan tingginya.

4. Beberapa komponen bagian kap lampu duduk digabung dengan cara membangun bidang batas antara dua komponen berdekatan dengan prosedur sebagai berikut.
a. Ditetapkan lingkaran atau poligon segienam beraturan tutup atas bagian alas komponen kap lampu duduk dengan jari- jari $r_{1}$ sebagai kurva batas $C_{1}(u)$.
b. Ditetapkan lingkaran atau poligon segienam beraturan tutup bawa bagian utama komponen kap lampu duduk dengan jari-jari $r_{2}$ sebagai kurva batas $C_{2}(u)$.
c. Bidang batas antara $C_{1}(u)$ dan $C_{2}(u)$ menggunaan persamaan (8). dibangun dengan interpolasi linier
d. Dilakukan langkah (a) sampai (c) untuk membangun bidang batas antara komponen utama kap lampu duduk dengan komponen atap kap lampu duduk.

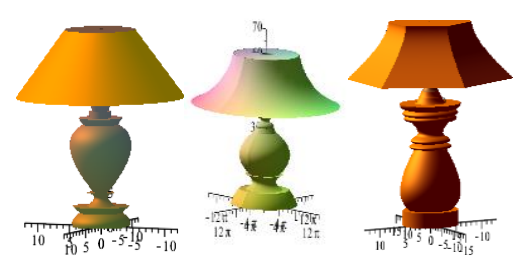

Gambar 14. Variasi Bagian Utama

\section{KESIMPULAN}

Berdasarkan hasil penelitian, diperoleh bahwa:

1. Merangkai komponen kap lampu duduk secarah utuh yaitu mengkonstruksi komponen-komponen kap lampu duduk, mengkonstruksi bagian-bagian dari kap lampu duduk (bagian alas, bagian utama dan bagian atap), langkah yang terakhir yaitu merangkai komponen kap lampu duduk secarah utuh.

2. Pemilihan parameter-parameter dan titik kontrol kelengkungan kurva akan menghasilkan bentuk-bentuk kelengkungan kurva yang berbeda sehingga bentuk kap lampu yang diperoleh bervariatif.

\section{DAFTAR PUSTAKA}

[1] Kusno, Geometri Rancang Bangun Studi Tentang Desain dan Pemodelan Benda dengan Kurva dan Permukaan Berbantu Komputer, Jember: Jember University Press, 2010.

[2] Kusno, A. Cahaya and M. Darsin, "Modelisasi Benda Onyx dan Marmer Melalui Penggabungan dan Pemilihan Parameter Pengubah Bentuk Permukaan Putar Bezier," Jurnal Ilmu Dasar, pp. 175-185, 2014.

[3] A. Cristiyyanto, "Perancangan Objek Tiga Dimensi dengan Teknik Flat Shading dan Gouraund Menggunakan Bahasa Turbo Pascal 7.0," Skripsi tidak dipublikasikan, 2003.

[4] M. Roifah, "Modelisasi Knop Melalui Penggabungan Benda Dasar Hasl Deformasi Tabung, Prisma Segienam Beraturan dan Permukaan Putar," Skripsi tidak dipublikasikan, 2013.

[5] A. Bastian, "Desain Kap LAmpu Duduk Melalui Penggabungan Benda-benda Geometi Ruang," Skripsi tidak dipublikasikan, 2010. 